\author{
Alekseev N. E., \\ Senior Lecturer at the Department of Foreign Languages № 1 \\ National University "Odesa Law Academy"
}

Alekseeva L.I., Lecturer at the Department of Foreign Languages of Professional Communication International Humanitarian University

Syniova T. V., Lecturer at the Department of Foreign Languages of Professional Communication International Humanitarian University

\title{
TRANSLATION COURSE FOR LAWYERS: EXCESSIVE KNOWLEDGE OR NECESSITY?
}

Summary. The article addresses the urgent issue of the appropriateness and prospects of teaching the theoretical and practical course of translation to professionals other than philologists. Growing international contacts and the processes of European integration have resulted in the increasing demand in translation which predetermines the topicality of the article. "Translation and interpretation" in this article is understood as translation and interpretation solely for the pair of languages Ukrainian-English, the choice being substantiated. The conclusions and propositions are deemed relevant solely for this country. The history of training translators and interpreters in Ukraine has been investigated with regard to the impact it has had on the current state of T\&I training. A comparative analysis of translators' training in Ukraine and some European countries (Austria, Belgium, Germany and Denmark) has been propounded. The article analyzes some of the problems of T\&I training, relevant both for Ukraine and for European countries, as well as the shortcomings that are characteristic only of the Ukrainian educational system. Directions and methods for resolving them have been proposed including deeper study of European best practice in this respect and more active involvement in research of mutually interesting theoretical and practical issues of T\&I training. The article summarizes the arguments in the discussion as to who can make a better translator: a linguist with a profound knowledge of a foreign language and specialized training or a professional in a certain field with sufficient knowledge of a foreign language. The conclusions propounded in the article read that the different types of translator's work require specific knowledge and skills and therefore it appears reasonable to employ graduates with a degree in technical subjects who also have excellent language skills for technical translations. It has also been emphasized that even good knowledge of a foreign language is insufficient for adequate translation and therefore, these specialists need additional training in theory and practice of translation. The range of professional translators' tasks has been outlined.

Key words: market of translation services, prospects of training translators, T\&I training, history of training translators and interpreters, professionals other than linguists, translatology, interpretation and conference translation.

The market of translation service as well as the nature and the scope of translators' and interpreters' work have undergone drastic changes, especially within the recent 20 years. This has occurred due to increasing expansion of international contacts in the world in general, and in Europe, in particular, on the one hand, and rapid development of information technologies, on the other hand.

Certain reservations should be made from the outset. Firstly, "translation and interpretation" in this article is understood as translation and interpretation solely from and into English. Secondly, the prospects of such a course are investigated in respect of Ukraine taking into account the tradition and present-day reality of language studies in this country and the national and international experience in translator's training. The situation in other countries may appear different and, therefore, the conclusions made in this article may be irrelevant in other cases. Thirdly, "lawyers" in the title may also apply to engineers, physicists or mathematics or, in fact, all professionals other than linguists.

The array of languages in this research is restricted to the pair Ukrainian-English for a number of reasons. Firstly, since the end of World War II, English has become a unique means of international communication, which fact has been almost unanimously recognized at all levels - linguistic, political, economic, etc. This is especially true for Europe where the English language has become a lingua franca [1]. In the National report on the training of translators and interpreters in Denmark, Karen M. Lauridsen mentions it as a fact that "English is basically regarded as the international lingua franca" in Denmark [2]. Moreover, the recent two decades have witnessed the emergence of a new phenomenon - European English, which appears to possess wide potential for further development and a possibility to become a distinct dialect of the English language [1]. Secondly, English has been chosen for this study from the viewpoint of practicability. In this country, it occupies the largest segment of educational programs both at the level of secondary and higher education. The example of the National University "Odessa Academy of Law" supports this viewpoint since the number of students who continue studying German and French does not exceed 10 per cent of all students. Further, a certain improvement in the quality of mastering English can be observed within the recent decade in Ukraine, although the results are clearly far more humble than those in Denmark (and many other European countries), where according to the National report on the training of translators and interpreters in Denmark, "The first foreign language for Danes is clearly English, which is an obligatory school subject from 4th form (age 10). Most Danes 
under the age of 50 can communicate quite well in everyday English" [2]. Nevertheless, quite a sizable number of Ukrainian students in their fourth/fifth year can demonstrate the proficiency in the English language that would be sufficient to start training in the fundamentals of translation and interpreting.

Therefore, the article aims at researching into the prospects of training professionals other than linguists in translation and interpretation. Rapid evolution of the international market of translation and the changes in the tasks and nature of the work performed by translators/interpreters determine the topicality of this research. The changing nature of and approaches to the training of translators and interpreters serves as the object of the study. The European and domestic practice of interpreters' and translators' training is the material of the investigation.

The development of IT technologies has brought radical changes to all spheres of human intellectual activity including translation. This has affected both the process of translation per se and translators' training. As has been justly marked by Christine Pagnoulle from the Université de Liège in the National Report on the training of translators and interpreters in Belgium, "All schools are now aware of the need to include computer skills in the training of translators. It is essential that a translator should be able to use modern information and communication technologies. In this respect courses on CAT and terminology management are indispensable" [2]. The National report on the training of translators and interpreters in Austria practically echoes, stating "....it will be necessary to enhance technical skills especially in the field of computer aided translation and the use of terminology data bases by establishing adequate training programs and providing access to existing databases" [2].

However, the effect of availability of numerous computer translation programs is not as unambiguous as it may seem at first glance. Undoubtedly, improved translation programs provide a possibility for practically every person, especially those having basic command of a foreign language, to perceive the meaning of a foreign text. It may create the impression with many people that they are able to translate - at least written texts - in all cases. However, the requirements for published texts, e.g. in scientific journals or educational manuals, still extend far beyond the possibility of machine translation. A similar picture becomes obvious during international scientific conferences, round-table discussions, etc. Professionals who can easily communicate with their colleagues, also about professional issues, are not able to provide adequate interpretation of reports and other materials, let alone to perform conference translation. This type of work has been traditionally performed by professional translators (interpreters). Therefore, the demand on the translation market in this country includes high-quality, or at least adequate translations and interpretations, traditionally in the wide sphere of knowledge.

Historically, the supply on the market of translations and interpretations in this country developed as follows: in the USSR, professional translators/interpreters were trained at a number of universities in Moscow and the capitals of union republics mostly to cover the needs of the diplomatic service. Military translators were trained at specialized faculties of military academies or recruited from civil specialists. All other jobs connected with translation, e.g. guide interpreters for the Intourist, were performed by graduates of philological departments of universities. On the other hand, a considerable bulk of technical translation was done by professionals in the corresponding field having some knowledge of a foreign language (languages). For this purpose, a 10 per cent increase in wages was provided for specialists who used foreign languages in their work and could prove their proficiency in a European language and 20 per cent was paid for an oriental or rare language.

This situation gave rise to discussions as to who can make a better translator: a linguist with a profound knowledge of a foreign language and specialized training or a professional in a certain field with sufficient knowledge of a foreign language.

The collapse of the Soviet Union brought new developments in the situation. The open borders and growing international contacts resulted in increasing demand for translation services in ex-Soviet republics including Ukraine. Soviet universities had developed a surprisingly efficient system of teaching foreign languages given that the majority of university graduates had not had a possibility to communicate with native speakers, let alone visiting the country where the language they studied was spoken. A student could graduate from a foreign languages department of a university, successfully complete a post-graduate course and finally defend his/her doctoral thesis without ever communicating with a native speaker. The only problem was that the language they spoke might have seemed too academic or bookish to a native speaker.

Closing of many educational and scientific institutions and galloping inflation of the 1990s forced these specialists to seek new application for their skills and translation seemed to be a natural choice, especially taking into account the growing demand. These people with good linguistic education generally did not take any special courses learning primarily by experience using the trial and error method. Further, the growing demand stimulated opening of a number of new, frequently commercial faculties at universities, which alleged to be training translators. Studying foreign languages, mainly English became even more prestigious than in the Soviet period since this received a clear possibility of practical use.

However, development and wide spread of IT technologies in the 2000s paradoxically slowed down the development of the translation profession since it narrowed the sphere of its practical application. Translation of numerous documents, including technical and business correspondence, which had been previously done by translators, was increasingly successfully performed by computers. This limited the sphere of a translator's work to the most complicated and important tasks and interpretation including conference translation. This work requires high qualification, which had been previously acquired in the course of practical work starting from easier tasks now performed by computers. In the late 1980s - early 1990s, tourist groups travelling to foreign countries were accompanied by interpreters who translated even everyday communication. This also became unnecessary thanks to the growth of awareness of foreign languages among the younger generation of Ukrainians.

Thus, the possibility for the linguists to acquire translator's competence through practice decreased, which gradually resulted in the decrease in the number of experienced translators available in the market. Presently, the professional translators and interpreters who are still available normally value their services higher. The situation that has been formed by to date frequently requires from the professionals remembering the saying "It's up to you to have a boat if you want to stay afloat" meaning that now they have to fully or partially perform the work, which was previously done by a professional translator/interpreter. 
The above said attaches new topicality to the already mentioned discussion as to who can make a better translator: a linguist with a profound knowledge of a foreign language and specialized training or a professional in a certain field with sufficient knowledge of a foreign language. The supporters of the latter standpoint usually argue that professionals have a better command of professional terminology in their mother tongue and, which is probably even more important, deeper perception of the inner logic of professional texts. They offer additional arguments saying in particular that "Faced with international business, many entrepreneurs quickly realized that full-fledged professional communication was simply impossible through the mediation of translators, and that their employees should not have just a good command of a foreign language, but first and foremost be highly qualified professionals" [3]. The above mentioned statement is supported by examples of actual employers' requirements for future employees.

M. Vatutin summarizes the arguments of the critics:

- adequate translation is impossible without "deep familiarization" with theories of translation;

- only linguists can know a foreign language;

- engineers cannot know a foreign language and they have "problems" even with their native language.

He further somewhat sarcastically noted that "it is difficult for linguists to somehow justify their "exclusivity" having only these unconfirmed tales in the arsenal" [3].

Despite all the sarcasm, these arguments cannot be ignored. Linguists normally do know both the foreign language(s) and the mother tongue better simply because they have spent far more time on learning them. Moreover, theoretical knowledge both in linguistics and "translatology" normally allows achieving better results in translation. This may not be critical for technical translation but remains of utmost importance for literary or diplomatic and often for legal translation/interpretation where not only the meaning, but also "shades" of meaning are essential. In addition, universities are making attempts to meet the challenge by introducing specialization in their curricula, e.g. translation in the sphere of law, IT, tourism, sciences, etc.

Further, deficiencies in training translators and interpreters in Ukraine add to the argumentation. Many of them are also inherent in the systems of T\&I training of European countries. One of the basic problems faced by Ukrainian faculties training translators and interpreters is lack of understanding of the specificities of such training, which is frequently basically similar to that of philological faculties. Similarly, the National Report on the training of translators and interpreters in Germany reads, that there is "...the tendency to equate T\&I training with foreign language training or more general "language studies" and that "only recently have there been efforts to develop course components specific to translation and interpretation courses" [2]. Among basic deficiencies in the system of T\&I training, the same report mentions "the lack of any official definition as to what qualifies a "translator" or "interpreter", and that despite recent attempts to address the problem "there is no generally accepted, official qualification required for using the designation "translator" or "interpreter" [2].

More or less successful attempts to address the deficiencies have been made both in European countries and Ukraine. They generally follow two directions:

Development of the theoretical basis. On a more general level this includes the theory of translation or "translatology" (a new term applied in some European countries [2]). More specifically, this means development of educational courses characteristic of T\&I training.

Bringing the curriculum closer to practice, i.e. to the requirements set by would-be employers.

The latter direction is usually viewed similarly to what is written by Antony Pym in "Training translators", "Some of the steps being taken to bring training closer to the market include inviting professionals into the classroom, assessing of students on the basis of portfolios of their completed translations, using real-world ('authentic') translation tasks with explicit instructions from a client, and generally modelling competencies and skill sets in ways that can match up with market demands" [4].

In addition to the deficiencies common for many European countries Ukrainian universities have individual problems in regard to T\&I training, the major being inadequate student mobility. Whereas in Austria, for example "exchange possibilities are being taken advantage of by a large proportion of $<\ldots>$ students, and are generally seen as an excellent opportunity to further the aims and objectives outlined in our curriculum. Both student mobility and teacher mobility have come to be regarded as a major factor in improving cross-cultural awareness and cooperation" [2], student exchange for Ukrainian higher educational institutions, especially in humanitarian sphere, remains an exception rather than a rule. Justly remarking that "where language enhancement is involved, staying in a foreign country where the studied language is spoken is essential", Christine Pagnoulle from Université de Liège, Belgium further notes that "most of the institutions $\langle\ldots\rangle$ have greatly benefited from exchange programmes, both standard ERASMUS/ SOCRATES exchanges and programmes involving Central and East European universities and institutions (TEMPUS)" [2]. Financial problems faced both by Ukrainian universities and their students largely hinder wide participation in these programs.

Although information technologies allow Ukrainian educational institutions maintaining general awareness of modern methods for T\&I training applied in EU countries, still lack of this country universities' involvement in European educational space can be regarded as an additional drawback of Ukraine's T\&I training system.

Taking account of the above said, certain conclusions can be made.

Firstly, in the present circumstances, translation by professionals other than linguists seems a reasonable option in many cases. This also goes in line with the European practice where "firms and institutions increasingly employ graduates with a degree in technical subjects who also have excellent language skills rather than translators" [2].

Secondly. Antony Pym in "Training translators" justly remarked, "Just as everyone can sing, be it badly or well, so everyone who knows more than one language can translate, to some degree. However, not everyone is paid to sing opera, and not all translators are at the pinnacle of the translation profession" [4]. It should be therefore understood that simply knowing a foreign language does not make a good translator. Taking into account the growing demand in translation, it appears expedient to train professionals (in our case - lawyers) with the sufficient knowledge of English in the basics of translation theory and practice. This is especially true in case of interpretation.

Thirdly, professional translators/interpreters remain indispensable in many spheres of international communication, primarily literature, journalism and culture in general and diplomatic service. The possibility of training professionals other than linguists 
for conference translation seems doubtful and impracticable. Therefore, conference translation will most probably remain the domain of professional interpreters.

Fourthly, since it appears highly unlikely that the financial situation in Ukrainian universities will change for the better, at least in the nearest future, domestic universities should continue developing other methods of improvement of their students' communication skills and achieve greater involvement in their European colleagues' attempts to develop professional standards and generally accepted, official qualification required for using the designation "translator" or "interpreter".

\section{References:}

1. Euro-English: peculiarities of evolution/N.E.Alexeyev,L.I.Alexeyeva, T.V. Synyova. Науковий вісник Міжнародного гуманітарного університету. Серія : Філологія. 2018. Вип. 33(2). С. $162-165$.

2. National Reports on the Training of Translators and Interpreters Appendix to the Final Report. URL: http://www.celelc.org/projects/ Past_Projects/TNP_Languages/TNP1_resources/SP7NatReps.pdf

3. Так ли уж нужны переводчики работодателям из научно-технической сферы? URL: http://forum.lingvolive.com/thread/d1182/

4. Antony Pym. Training translators. URL: https://www.researchgate.net/ publication/297128820_Training_Translators

5. Легко ли быть переводчиком? URL: http://fridge.com.ua/2009/04/ legko-li-byit-perevodchikom/

6. Baer, B.J., and Geoffrey S. K., eds. (2003), Beyond the Ivory Tower. Rethinking Translation Pedagogy, Amsterdam and Philadelphia : Benjamins.

7. Bowker, L. (2004), 'What does it take to work in the translation profession in Canada in the 21 century? Exploring a database of job advertisements', Meta 49 (1): 960-972.

8. González Davies, M. (2005), 'Minding the process, improving the product: Alternatives to traditional translator training' / Martha Tennent (ed.) Training for the New Millennium. Pedagogies for Translation and Interpreting (Amsterdam and Philadelphia: Benjamins).

Алскссєв М.Є., Алскссєва Л.І., Синьова Т.В. Курс перекладу для юристів: надмірне знання чи необхідність?

Анотація. У статті розглядається нагальне питання доцільності та перспектив викладання теоретичного та практичного курсу перекладу для фахівців певних спеціалізацій, окрім філологів. Зростання міжнародних контактів та процесів європейської інтеграції призвели до зростання попиту на переклад, що зумовлює актуальність статті. «Переклад та усний переклад» у цій статті розуміється як усний та письмовий переклад виключно для пари мов українсько-англійська, вибір яких у статті був обгрунтований. Висновки та пропозиції вважаються актуальними виключно для нашої країни. Історію підготовки фахівців 3 усного та письмового перекладу в Україні було досліджено з огляду на вплив, який вона мала на сучасний стан підготовки фахівців з усного та письмового перекладу. Було проведено порівняльний аналіз підготовки перекладачів в Україні та в деяких європейських країнах (Австрія, Бельгія, Німеччина та Данія). У статті проаналізовано деякі проблеми навчання T\&I, актуальні як для України, так і для європейських країн, а також недоліки, характерні лише для української освітньої системи. Запропоновано напрями та методи їх вирішення, включаючи більш глибоке вивчення найкращої європейської практики в цьому відношенні та активнішу участь у дослідженні взаємно цікавих теоретичних та практичних питань тренінгу з питань науково-технічних досліджень. У статті були узагальнені аргументи дискусії щодо того, з кого може вийти кращий перекладач: із лінгвіста із глибоким знанням іноземної мови та спеціальною підготовкою або професіонала певної галузі зі знанням іноземної мови. У висновках, викладених у статті, випливає, що різні види роботи перекладача потребують конкретних знань та навичок, і тому видається розумним працевлаштування випускників зі ступенем технічних предметів, які також володіють чудовими знаннями мови для технічного перекладу. Також було підкреслено, що навіть хорошого знання іноземної мови недостатньо для адекватного перекладу, а тому цим спеціалістам необхідна додаткова підготовка з теорії та практики перекладу. Окреслено коло завдань професійних перекладачів.

Ключові слова: ринок перекладацьких послуг, перспективи підготовки перекладачів, навчання T\&I, історія підготовки письмових та усних перекладачів, фахівцінефілологи, усний послідовний та синхронний переклад. 